\title{
Dynamics for Shifting the Ethio- Egyptian Hydro Political Relations
}

\author{
Yayew Genet Chekol $^{1}$ \\ ${ }^{1}$ Lecturer, Department of Political Science and International Relation, College of Social Science, Dire Dawa University, \\ Ethiopia \\ Correspondence: Yayew Genet Chekol, Lecturer, Department of Political Science and International Relation, College of \\ Social Science, Dire Dawa University, Ethiopia.
}

\author{
Received: June 11, 2018 \\ Accepted: July 15, $2018 \quad$ Available online: July 30, 2018 \\ doi:10.11114/ijsss.v6i8.3492 \\ URL: https://doi.org/10.11114/ijsss.v6i8.3492
}

\begin{abstract}
The foremost intent of this study was to investigate the major dynamics that are reversing in Ethio-Egyptian hydro political relations. To attain this objective the researcher employed case study design, primary and secondary sources of data, and purposive sampling techniques. Despite the fact that perpetual national interests on Egyptian Nile water policy as national security issue, dynamics are revealing in the Nile basin which fosters to shift the relations of Ethiopia and Egypt hydro political relations on Nile water. Regarding with the findings of the study relative growing power of Ethiopia, Egyptians commitments on efficient utilization of water resource, Egyptian revolution, the signing of CFA by upper stream countries, the independence of South Sudan, the launching of GERD by Ethiopian, signing of DOPS by Ethiopia, Sudan and Egypt on GERD are the new political dynamics in the Nile basin which geared to shift the relation of Ethiopia and Egypt.
\end{abstract}

Keywords: Ethiopia, Egypt, hydropolitics, dynamics, Nile

\section{Introduction}

\subsection{Overview of the Antique Struggle for the Nile Water}

Ethiopia and Egypt have had a long relationship of both harmony and discord, the latter the result of religious issues and access to the Nile water, among other factors. The relations between Egypt and Ethiopia went back to the early years of Axumite kingdom. This means they have been in contact for centuries which seem to have been based on the Red Sea trade. Not only this, there is a long and important link between the minority Egyptian Coptic Church and the Ethiopian Orthodox Church. However, the relationship of the two States is older than the relations between the churches. To substantiate this contention there are historians who indicate that the early Ethio-Egyptian contact dates back to 2800 B.C, (Waterbury, 2000).

Egyptians tried to locate the source of Blue Nile and its tributaries, historical relics found in the tombs of pharaohs and inscriptions found on the tomb of Titmos. The relics, mentions places like Adulis, and Tigre, thereby indicating early contacts Ethiopia had with Egypt (Tadesse, 2013).

In recent past, Egypt and Ethiopia fought over control of the red sea and upper Nile basin. The climax came in 1876 at the battle of Gura in present day Eritrea where the Ethiopian delivered a humiliating defeat to the Egyptian army (Aaron, 2005).

Coming to the colonial era, the European partition of Africa in the 1880s added a huge complexity to this conflict. Colonization created many new states in the basin. Uganda, Rwanda, Burundi, Kenya and Tanganyika set off new competition for resource and territory (Petros, 2010). In the late nineteenth century controlling Egypt was the key to Asian wealth, and since Egypt depended on the Nile, controlling the source of the Nile becomes a major colonial goal (Degefu, 2003).

The French and English colonial competition to control the Nile basin touches its climax in 1898 at Fashoda. The French conceived of building a dam on the White Nile so as to undermine British influence further down river and establish east- west control of the continent. They organized a stupendous pincer movement with one group of soldiers travelling from east Africa across Ethiopia and the other from West Africa across the Cong o (Degefu, 2003). 
The British heard of the French expedition, and having just captured Khartoum ordered a fleet of gun boats and steamers with soldiers under the leadership of general Horatio. With fewer than 200 men, the French were embarrassed. In 1889 the two colonial powers reached an agreement which designated to France the frontiers of the Congo River and to England the frontiers of the White Nile (Elrich, 2002).

The Fashoda incident revealed how little Europeans understood about the Nile River. Thinking that most of the Nile waters came from the equatorial lakes (Victoria, Albert, Kyoga, and Edward), the English spent enormous energy on plans to increase White Nile water flows (Elrich, 2002).

First called the Garstin cut and later the Jonglei canal, the British intended to create a channel that would maximize water transfer through the great swamp (where half of it evaporated). One of the most expensive engineering projects in Africa; the Jonglie canal was terminated in 1984 by the Sudan People's Liberation Army, because of the severe disruption it brought to the lives of the indigenous upper Nile peoples. If the 300 mile long Jonglei canal had been completed, it would have increased water flows by nearly 4 billion cubic meters in to the White Nile (Elrich, 2002). These hydro political and historical incidents have shown that there were increased ambitions to control the Nile water resources even their demand included controlling the of water sources of Nile. The major Intent of this study is to investigate the political dynamics of the Nile riparian state that foster to shift the Ethio-Egyptian hydro political relations.

\section{Materials and Methods}

In this study qualitative approach is appropriate to investigate Ethio-Egyptian relations on the Nile River and the researcher employed a case study design according to the sample and participants of the study, officials who work in Ministers of Foreign Affairs particularly in the directorate of research and policy analysis, Ministry of water, irrigation and electricity particularly trans-boundary rivers directorate and NBI coordinator official, diplomat from Egypt Embassy in Addis Ababa and other scholars were served as key informant. The place of the interview was in Addis Ababa. The researcher conducted key informant interviews and available documents, which are written on the Ethio-Egyptian hydro political relations, were served as secondary data sources. The researcher employed thematic analysis to analyze different sets of data collected from various sources.

\section{Dynamics that Are Shifting the Ethio-Egyptian Nile Hydro Political Relations}

This study investigated various dynamics that convey about vicissitudes in Ethio-Egyptian hydro-political relations. These are Ethiopian's aggregate political power in the basin, the signing of CFA by upper stream states, Egyptian revolution, the launching of GERD, signing of DOPS on GERD by Egypt, Ethiopia and Sudan, and the inclination of Egypt for proficient utilization of Nile water resources in the basin.

\subsection{Ethiopian Comparative Growing Power}

The result of this study shows that the emergent of Ethiopia's political and economic power was one factor that brings change in Ethio-Egyptian hydro-political relations. Ethiopia passed many challenges such as civil war, political instability, and hunger to reach for today's stable political and economic change (Cascou, 2009).Such historical barriers along with Egyptians historical claim to use the Nile unilaterally caused Ethiopia to be relatively disadvantageous in utilizing Nile water resource. However, this study showed that such power of Egypt has been challenged because of Ethiopian's growing power in terms of political and economic spheres. Such growing of power enables Ethiopia to use its potential water resources for country's development by challenging the historic power of Egypt. In relation to this a participant stated that:

Today Ethiopia is relatively politically stable in the Nile basin states. There is the driving force that Ethiopia concentrates its financial resources for development areas such as poverty eradication program and water resource developments. The country has potential resources that enable to generate hydroelectric power and agricultural irrigation, which brings economic growth. Such growth of economy enabled Ethiopia to start developing water resource projects irrespective of Egyptians interest (Interviewee 01, 2016).

GDP in Ethiopia was worth 61.54 US dollar in 2015. The GDP Value of Ethiopia represents 0.10 percents of the world economy as the GDP reported by World Bank (2016). According to the report, the GDP expanded 9.60 in 2015 from the previous year's. The report addresses that Ethiopia is one of the poorest countries in the world. Most of the populations rely on subsistence agriculture and foreign aid. Yet Ethiopia is amongst the fastest growing non oil economies in the world .The government reforms succeeded in opening the economy to foreign direct investment and resulted in expansion of commercial agriculture and manufacturing industry (World Bank, 2016).

The statement given by this interviewee and the World Bank report clearly indicated that there is a change in Ethio-Egyptian hydro-political relations because of Ethiopia's economic growth in one hand and its political stability on the other hand. Its economic growth enables Ethiopia to develop water resource projects by its own 
finance. In line with this, Cascou (2009) affirmed that recently there is a relative increase of economic and political stability in Ethiopia that lead to increase its desire to develop water resources. This writer also stated that Ethiopia is able to fund development projects without resorting to international donor agencies, such as the World Bank. Moreover, the increased political stability in Ethiopia has allowed the country to concentrate its financial resources in the development areas other than defense.

The other participant also stated as "the political and economic growth of Ethiopia enables to develop mega projects in the Blue Nile unilaterally despite there is some challenges from downstream states particularly from Egypt" (Interviewee 01, 2016). Ferah (2011) also argued that Ethiopia can jump start its water resource development without inputs from Egypt .In general, the study found that Ethiopia's growing power in economic and political areas resulted changes in Ethio-Egyptian hydro political relations.

\subsection{Egypt's Commitment for Proficient Utilization of Nile}

This research also showed that the Egyptian's commitment to utilize its water resources efficiently is the other factor that brings change in its relation with Ethiopia. As participants clearly indicated, this commitment is a manifestation for Egypt to become in to cooperation in utilizing water resources with other riparian states particularly with Ethiopia. In this regard, an Egyptian official from Addis Ababa stated that "Egypt is ready to recycling water resources up to house hold level and utilize it properly (Interviewee 03, 2016). Similarly, Ethiopian official also argued that Egypt has showed its commitment to use water resources efficiently particularly following the conclusion of the agreement on GERD, which in turn shows its readiness to inter in to CFA (Interview 02, 2016).

The main point here is that Egypt's commitment to utilize water resources efficiently indicates its interest to enter in to cooperation in using water with other riparian states. This in turn shows its readiness to create smooth relation with Ethiopia towards using the Nile River.

\subsection{Egyptian Revolution}

On February 11, 2011, Egyptian President Hosni Mubarak resigned from office after 18 days of protests. The gloomy prospects surrounding the use and allocation of the Nile waters seem to have improved following the 2011 Egyptian revolution that forced Mubarak to resign from power and brought about political change in the country. One Egyptian official stated the idea that "The present government in Egypt is opened to negotiation process regarding with the Nile respective of the state national interest, and the Ethiopian government has strong stand on cooperation with Nile River regarding with public interest and other developmental issues"(Interviewee, 03, 2016). Many, including some Egyptians, believe that the recent political change in Egypt will boost the chances of reaching a new deal to equitably share the Nile waters (Interviewee 04, 2016). This shows that the new regime is opened for discussion among the riparian states of the Nile basin, particularly it is the nearest to Ethiopia comparing with the previous Hosni Mubarak's ruling period .Therefore since Egypt revolution is the reason for changing the regime it is in turn also the factor for changes of Ethiopia and Egypt hydro political relation.

It seems that Egypt has changed its rules of engagement with upstream countries, particularly Ethiopia, in relation to the Nile question. This sign of rapprochement has been reinforced by the recent visit of a 48 member of Egyptian public diplomacy delegation and Egypt's Prime Minister Essam Sharaf to discuss the Nile River (Bayeh, 2015)

\subsection{The Validation of CFA by Upstream Riparian}

After ten years of negotiation the countries of the Nile Basin come up with the cooperative Framework Agreement, which firmly founded on the principle of equitable and reasonable utilization of the Nile waters. In line with this, article 4(1) of the CFA declares that "Nile Basin states shall in their respective territories utilize the water resources of the Nile River Basin in an equitable and reasonable manner. It is a means to create positive sum game between them where the entire riparian are determined to win. The NBI achieved tangible progress in 2010, when four of its members met in Kampala, Uganda to sign the CFA treaty. Uganda, Tanzania, Rwanda and Ethiopia signed, followed shortly by Kenya. Burundi signed the CFA in February 2011 bringing the number of signatories to six. South Sudan has also joined in June 2013 and Democratic Republic of Congo is expected to join soon. However, Egypt and Sudan have still persisting not to sign the agreement with the aim of maintaining the status quo (MOWIE, 2015).

The major point of difference between up and down stream states is on point that the Nile Basin states agree, "Not to significantly affect the water security of any other Nile Basin states". Nevertheless, Egypt and Sudan refused this statement and Egypt proposes its substitute by "not to adversely affect the water security and current uses and rights of any other Nile Basin state". For this reason, in order to convince the downstream states to sign the CFA, upstream countries are exerting their effort diplomatically to bring them to round table discussion.

According to Egyptian official (interviewee 03, 2016) stated "Egypt is discussing with the internal political decision 
makers to sign the CFA". For this reason, NBI has played its contribution to come up with riparian countries to cooperatively utilize the Nile water resource particularly the CFA signatories have sent the unusual message to Egypt. In the CFA signatories Ethiopia has hegemonic power geopolitically and internal political stability. It has also the ability to shift Egypt's hydro hegemony power on Nile water.

\subsection{The Objectivity of South Sudan}

The objectivity or independence of South Sudan in July 2011 and therefore the emergence of a new riparian state hard core for the Sudd Swamps, an ecosystem crucial for the flow of the White Nile due to its large evaporation rates, have the potential of influencing upstream-downstream relations by new coalition opportunities. The creation of South Sudan as an independent state has both advantage and disadvantage: since regional tensions over water management and distribution have grown lately, the birth of an independent Southern Sudan would exacerbate this problem by adding another player to the game of Nile politics, which already involves an unmanageable number of states. On the other hand, Due to its strategic location, independent South Sudan would robustly brought adjustment and shift of power balance in the Nile basin because South Sudan is vital state in the Nile basin since most of its geography lies in the Nile basin (Kenyi, 2011). This author added that emergence of independent South Sudan in the Nile basin caused enormous panic to downstream countries. Existence of new Sovereign entity in the Nile basin has direct and indirect impact on both Ethiopia and Egypt. Emerged state and her massive land incorporated much of White Nile with gigantic potential of hydroelectric power and planned to engage in constructing hydro power stations by its own after discussing with upstream countries.

That is why Paul Mayom, Minister of Water Resources \& Irrigation of the Republic of South Sudan said on admission of the Republic of South Sudan to the Nile Basin Initiative that "The decision you took today will be received with cheerful applause by the Government and the people of South Sudan. This is because South Sudan geographically falls wholly within the Nile River Basin and therefore, our growth and prosperity are undoubtedly linked to the developments within the Nile River Basin,"(Sudan Tribune, 2013:6). Thus, we can easily understand from Mr. Mayom's speech that how much weight South Sudanese gave to the Nile River. Egyptian official (Interviewee 03, 2016) stated that for the issue of Nile hydro politics South Sudan is nothing to contribute for water volume but Egypt is ready for supporting south Sudan for its internal instability and for the resolution of the government and the opposition parties' conflicts.

Despite, the official has downgrading the stake and contribution of South Sudan in the hydropilitics of Nile; it is arguable that South Sudan does have a stake in the hydropolitics of Nile. In this regard, Salman (2011) has written as "Because of the size of the White Nile in South Sudan, the heavy water losses at the swamps there and the possibility of conservation of a good part of such water, the stakes of South Sudan can be classified as very high, almost at par with Egypt, Ethiopia and the Sudan."

This indicates that South Sudan has an influence in the hydro politics of Nile and its emergence as independent state and subsequently its inclination to the upstream countries is considered as one reason is changing the hydropolitical relation of Egypt and Ethiopia.

\subsection{The Launching of GERD by Ethiopia}

In April 2011, Ethiopia announced its plan to build the 6000 Megawatt Ethiopian Renaissance dam. The reservoir will be the largest water-body in Ethiopia, with a capacity of 63 billion cubic meters water, twice the size of the largest natural lake in Ethiopia, Lake Tana. This project is being constructed at the very course of the Blue Nile that contributes about $86 \%$ of the total Nile waters, some 40 kilometers away from the eastern boundary of the Sudan. During the launching of the project, the late Prime Minister MelesZenawi said it would cost about 80 billion Birr (about 4.8 Billion USD) that would be covered domestically (Hammond, 2013). This was because Egypt had successfully lobbied against Ethiopia receiving access to external loans and grants.

According to Ethiopian government, the construction of the Grand Ethiopian Renaissance Dam(GERD) over the Nile River is one of the major projects that could play major and decisive role in realizing the five-year Growth and Transformation Plan and the consequent advance towards the eradication of poverty. The project is believed to improve the country's electric and energy needs by providing for between 65 and 87 percent of the entire power supply the country expects to generate over the period of the plan (MOWIE, 2015). In addition, The Ethiopian Government has argued that as well as supplying Ethiopians with electricity, the dam would generate surplus energy for export to neighboring countries, benefitting the wider region. The Ethiopian government further argues that the building of the GERD is a good opportunity for Sudan and Egypt. For instance, Sudan spent 70 percent of its water budget to avoid the silt. This is also a problem for Egypt. However, the building of the GERD could help these countries to receive filtrated water. The Second important advantage of this Dam is that it reduces the flood that causes property damage every year in these countries. It is Ethiopia also believed that the two countries: Sudan and 
Egypt, will get more water due to the building of the GERD as Ethiopian rivers fully flow only for about four months a year and then decrease, the amount of water that the two countries could receive has also decreased.

Thus, the flow of water will be the same throughout the year if the GERD is built. Last but not least, the Dams in Sudan and Egypt have no power of retaining evaporation. The GRD, however, is in a deep gorge that it could decrease water evaporation so that the amount of water for the two countries could be increased.

Despite the fact that Egypt is not comfortable with the construction of the GERD, the new Egyptian government is partially succeeding in strengthening cooperation with upper riparian countries, in contrast to the actions of the former Mubarak government. The attitude of many politicians in Sudan, and perhaps also the government, seems to be one of positive expectation towards the Dam. For instance, Al-Basher, Sudanese president, on his behalf recently told the press that his country will provide the necessary support towards success of construction of the Grand Ethiopian Renaissance Dam since the project would help Sudan improve the flow of water in the summer and overall increase the amount of water available to his country. Similarly, Egypt's Prime Minister Essam Sharaf during his visit to Ethiopia said this has opened a "whole new environment" for settlement of the longstanding dispute over sharing the waters of the Nile River (week in the horn, 2013).

According to (Tewodros, 2014) the Grand Renaissance Dam has mobilized Ethiopians from all corners of the world in the manner of no other cause in recent history. It has proved a stronger bond than ethnic, religious, political or any other affiliation. It is not exaggeration to say that it is in fact further cementing the unity of Ethiopians in a manner to help ensure Ethiopia's Renaissance in the shortest possible time. This also provides the great political legitimacy to the ruling government with comparing the previous years.

\subsection{Ethiopia, Sudan and Egypt Signed Declaration of Principles on GERD}

In 2015 Ethiopia, Sudan and Egypt signed an agreement on a Declaration of Principles on the Grand Ethiopian Renaissance Dam in Khartoum. Ethiopian Prime Minister Hailemariam Desalegn, Egypt's President Abdel Fattah El SiSi and Sudan President Omar Al- Bashir signed the agreement. Others attending the occasion included the Vice-President of South Sudan, James WaniIgge, as well as officials, representatives from IGAD, the Nile Basin Initiative, the World Bank and other international organizations (interviewee, 04, 2016).

In the Preamble to the Declaration of Principles (DOPS) the three countries enter into the signing of the Declaration mindful of the rising demand of their transboundary water resource, and cognizant of the significance of the River Nile as the source of livelihood. By laying down the Principles relating to the GERD, the document under lines its historic importance. It also demonstrates that cooperation is the only way to solve disagreements and enhance confidence and trust among the three countries regarding the GERD. To this end, the three countries have agreed "to cooperate based on common understanding, mutual benefit, good faith, win-win and principles of international law and in understanding upstream and downstream water needs in its various aspects (DOPS, 2015). In DOPS (2015) endorsed in the Declaration are: the Principle of Cooperation; the Principle of Development, Regional Integration and Sustainability; the Principle of Equitable and Reasonable Utilization; the Principle of Not to Cause Significant Harm; The Principle to Cooperate on the First Filling and Operation of the Dam ;the Principle of Confidence Building; the Principle of Exchange of Information and Date; the Principle Dam Safety; the Principle of Sovereignty and Territorial Integrity ; and the Principle of Peaceful Settlement of Disputes.

The Declaration of Principles (2015) endorses the point that the benefits of the GERD are for the whole region "through generation of sustainable and reliable clean energy supply" which is itself an important input "to contribute to economic development, promotion of trans boundary cooperation and regional integration. "The Declaration is a crucial document in the sense that it also rejects any past mistrust and suspicion. The three riparian states have now opted for cooperation and utilization of their transboundary watercourses on the basis of internationally accepted principles: the "principles of equitable and reasonable utilization and not to cause significant harm."

Another central point in the Declaration is that the three countries, as owners of the issues, have opted for an internal mechanism for peaceful settlement of disputes. This crucial point demonstrates the level of trust and confidence that the three countries are reaching. In effect, the signing of the Declaration of Principles has brought the Ethiopia and Egypt relations closer together. The Ethiopian officials admirably responded that there is a new era which shows the changing situation in Ethiopia and Egypt relation on Nile in history. It is the first time that Egypt clearly recognizes and takes part on the practical Nile water development by Ethiopia in the ground.

\section{Conclusion}

This study showed that there are recent developments that indicate Egypt's readiness to sign CFA, of which country's 
signing of DOPS with Ethiopia and Sudan is the main one. Since 1999 the power of Egypt has been challenged because of Ethiopia's comparative growing power in terms of political and economic spheres. Such growing of power enables Ethiopia to use its potential water resources for country's development by challenging the historic power of Egypt. Egypt's commitment to utilize water resources efficiently indicates its interest to enter in to cooperation in using water with other riparian states. This in turn shows its readiness to create smooth relation with Ethiopia towards using the Nile River. Egyptian revolution is the reason for changing the regime of Egypt; it is in turn also the factor for the changes of Ethiopia and Egypt hydro political relation. In addition to these, independence of south Sudan, the signing of CFA by upstream states, the launching of GERD, and the signing of DOPS by Ethiopia, Egypt and Sudan are the governing factors that foster changes in Ethiopia and Egypt hydro political relations.

The basic changes and the reasons for changes in Nile River are driven from the intrinsic demands of the upstream states of the Nile basin. Particularly the demand is to eradicate poverty, to balance economic growth with population growth and to cultivate the uneven climate in the region. The other driving force is political stability of the upstream states. Particularly Ethiopia's performance in political stability is better from upstream states. This political stability and other aforementioned national demands push the autonomous utilization of the Nile by Ethiopia without the aids of international financial institution.

To withstand such modifications Ethiopia should cooperate not only with upstream states but also with Egypt. Ethiopia should also consolidate its political and economic power to embark on different water development projects.

\section{References}

Aaron, A. (2005). Hydropolitics and Regional stability in the Nile Basin, William Patterson University, Wayne, NJ.

Bayeh, E. (2015). New development in the Ethio-Egypt relations over the Hydropolitics of Nile: Questioning itstrue prospects. Inter. J. Polit. Sci. Develop, 3(3), 159-165.

Cascão, A. E. (2009). Changing power relations in the Nile river basin: unilateralism vs. Cooperation. Water Alternatives, 2(2), 245-268.

Degefu, G. (2003) the Nile, historical legal and developmental perspectives. New York, Trafford publishing's Erlich, Haggai. The Cross and the River: Ethiopia, Egypt, and the Nile. London: Lynne

Ferah, H. (2011). Cooperation Over Water in the Eastern Nile Basin: Obstacles\& Opportunities, Duke University

Hammond, M. (2013). "The Grand Ethiopian Renaissance Dam and the Blue Nile: Implications for transboundary water governance" Discussion Paper 1307, University of Exeter, United Kingdom.

Horn. (2013). "Egypt's Public Diplomacy Delegation and Budding Regional Cooperation in the Eastern Nile area" in Week in the Horn, weekly article.

Kenyi, F. (2011). "Water security and Hydro -politics of the Nile River: South Sudan's National security in 21st century".

MoFA. (2013). "A week in the Horn”. An Online Publication covering developments in the Horn of Africa, 2(8).

MoWR. (1999). Ethiopian Water Resources Management Policy. Ministry of Water Resources, Addis Ababa.

Petros, G. (2010). No more thirst: the citizens of the Nile Addis Ababa, Rehobot printers.

Salman. (2013). The Nile Basin Cooperative Frame work Agreement: peacefully unfolding African spring? Water International, 38(1), 17-29.

Sudantribune. (April9, 2014). South Sudan's conflict and Egypt's hydropolitics.

Tedros, A. (2014). "The Nile is a Symbol of Cooperation and Collaboration", Available at: http://www.ethiopianembassy.it/docs/The_Nile_Symbol_of_Cooperation_and_Collaboration.pdf

Waterbury, J. (2002). The Nile Basin: national determinants of collective action. New Haven, London: Yale University Press.

World Bank. (2016) .Ethiopian over view, http/ www.world bank_org/en/country/Ethiopia/ retrieved on July. 2016

\section{Copyrights}

Copyright for this article is retained by the author(s), with first publication rights granted to the journal.

This is an open-access article distributed under the terms and conditions of the Creative Commons Attribution license which permits unrestricted use, distribution, and reproduction in any medium, provided the original work is properly cited. 